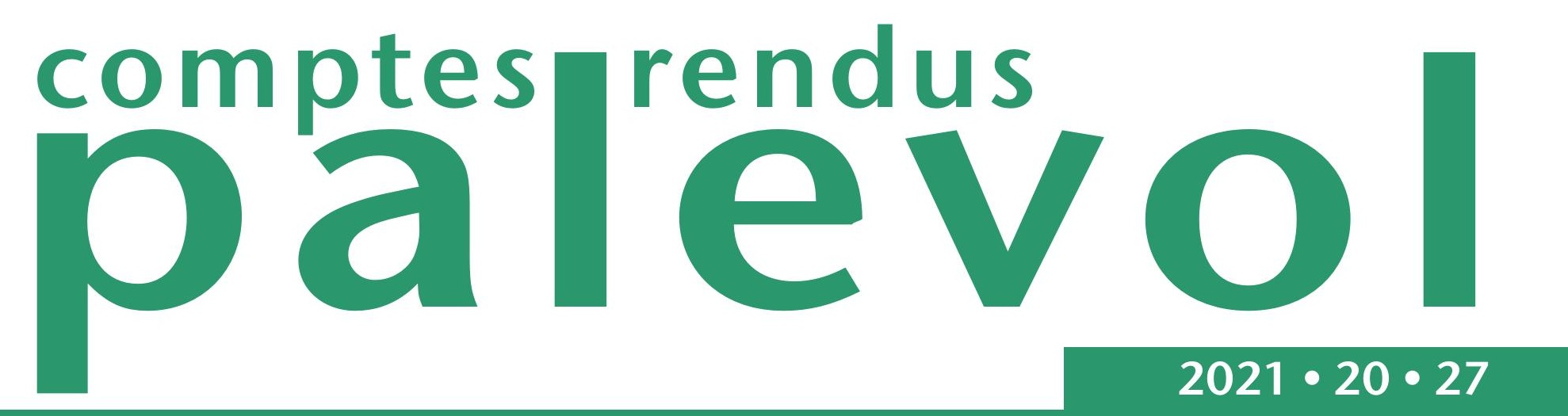

Tetraodontiformes (Osteichthyes, Actinopterygii) from the Miocene of Argentina: with the southernmost record of fossil Tetraodontidae

Soledad GOUIRIC-CAVALLI, Maria de la Mercedes AZPELICUETA \& Alberto L. CIONE

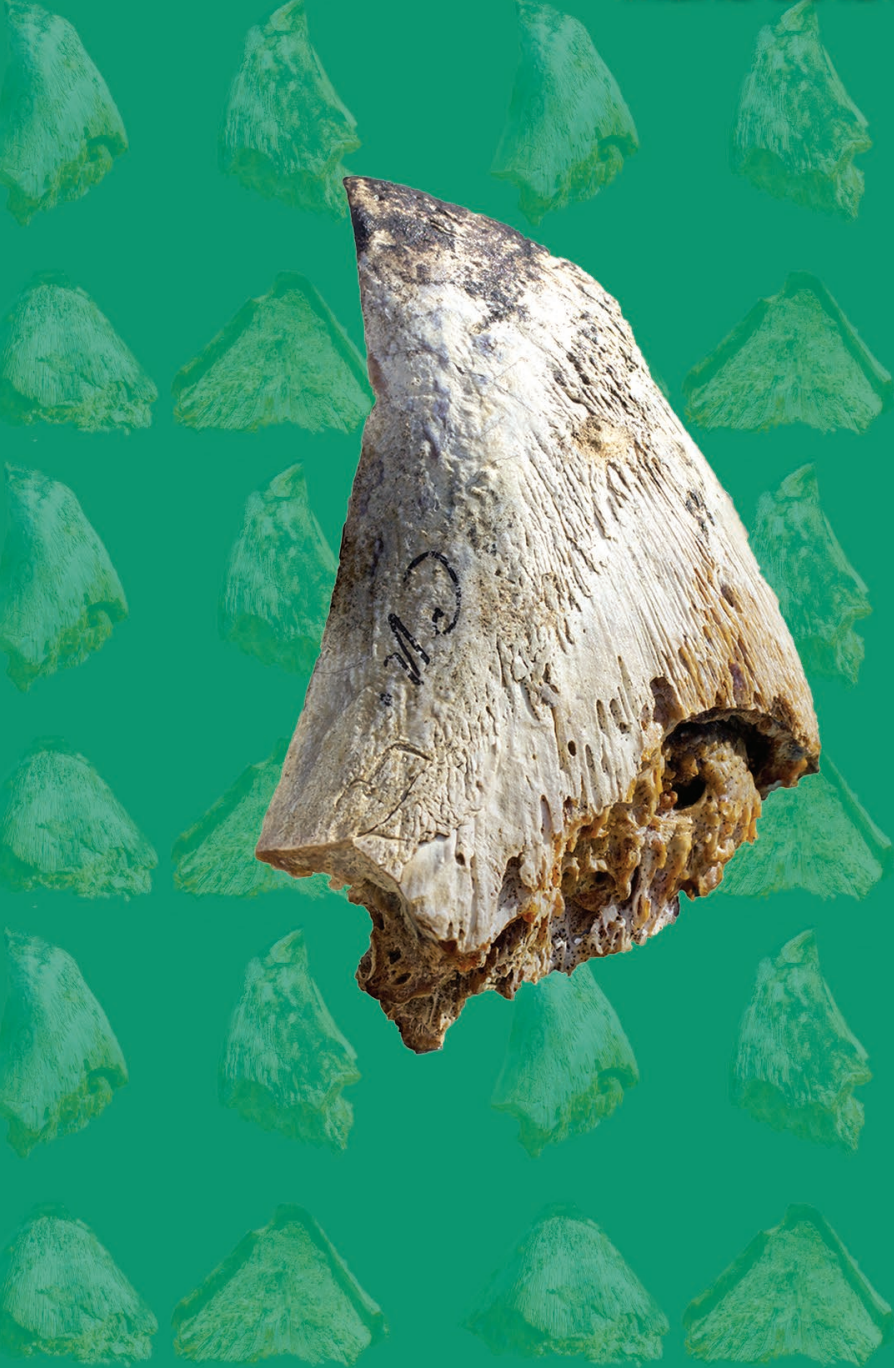


DiRECTEURS DE LA PUBLICATION / PUBLICATION DIRECTORS:

Bruno David, Président du Muséum national d'Histoire naturelle

Étienne Ghys, Secrétaire perpétuel de l'Académie des sciences

RÉDACTEURS EN CHEF / EDITORS-IN-CHIEF: Michel Laurin (CNRS), Philippe Taquet (Académie des sciences)

AssistANTE DE RÉDACTION / AssistANT EDITOR: Adenise Lopes (Académie des sciences; cr-palevol@academie-sciences.fr)

MISE EN PAGE / PAGE LAYOUt: Audrina Neveu (Muséum national d'Histoire naturelle; audrina.neveu@mnhn.fr)

RÉVISIONS LINGUISTIQUES DES TEXTES ANGLAIS / ENGLISH LANGUAGE REVISIONS: Kevin Padian (University of California at Berkeley)

RÉDACTEURS ASSOCIÉS / ASSOCIATE EDITORS (*, took charge of the editorial process of the article/a pris en charge le suivi éditorial de l'article):

Micropaléontologie/Micropalaeontology

Maria Rose Petrizzo (Università di Milano, Milano)

Paléobotanique/Palaeobotany

Cyrille Prestianni (Royal Belgian Institute of Natural Sciences, Brussels)

Métazoaires/Metazoa

Annalisa Ferretti (Università di Modena e Reggio Emilia, Modena)

Paléoichthyologie/Palaeoichthyology

Philippe Janvier* (Muséum national d'Histoire naturelle, Académie des sciences, Paris)

Amniotes du Mésozoïque/Mesozoic amniotes

Hans-Dieter Sues (Smithsonian National Museum of Natural History, Washington)

Tortues/Turtles

Juliana Sterli (CONICET, Museo Paleontológico Egidio Feruglio, Trelew)

Lépidosauromorphes/Lepidosauromorphs

Hussam Zaher (Universidade de São Paulo)

Oiseaux/Birds

Eric Buffetaut (CNRS, École Normale Supérieure, Paris)

Paléomammalogie (mammifères de moyenne et grande taille)/Palaeomammalogy (large and mid-sized mammals)

Lorenzo Rook (Università degli Studi di Firenze, Firenze)

Paléomammalogie (petits mammifères sauf Euarchontoglires)/Palaeomammalogy (small mammals except for Euarchontoglires)

Robert Asher (Cambridge University, Cambridge)

Paléomammalogie (Euarchontoglires)/Palaeomammalogy (Euarchontoglires)

K. Christopher Beard (University of Kansas, Lawrence)

Paléoanthropologie/Palaeoanthropology

Roberto Macchiarelli (Université de Poitiers, Poitiers)

Archéologie préhistorique/Prehistoric archaeology

Marcel Otte (Université de Liège, Liège)

RÉFÉRÉS / REVIEWERS: https://sciencepress.mnhn.fr/fr/periodiques/comptes-rendus-palevol/referes-du-journal

COUVERTURE / COVER:

Made from the figures of the article.

Comptes Rendus Palevol est indexé dans / Comptes Rendus Palevol is indexed by:

- Cambridge Scientific Abstracts

- Current Contents ${ }^{\circledR}$ Physical

- Chemical, and Earth Sciences ${ }^{\circledR}$

- ISI Alerting Services ${ }^{\circledR}$

- Geoabstracts, Geobase, Georef, Inspec, Pascal

- Science Citation Index ${ }^{\circledR}$, Science Citation Index Expanded ${ }^{\circledR}$

- Scopus ${ }^{\circledR}$.

Les articles ainsi que les nouveautés nomenclaturales publiés dans Comptes Rendus Palevol sont référencés par / Articles and nomenclatural novelties published in Comptes Rendus Palevol are registered on:

- ZooBank ${ }^{\circledR}$ (http://zoobank.org)

Comptes Rendus Palevol est une revue en flux continu publiée par les Publications scientifiques du Muséum, Paris et l'Académie des sciences, Paris Comptes Rendus Palevol is a fast track journal published by the Museum Science Press, Paris and the Académie des sciences, Paris

Les Publications scientifiques du Muséum publient aussi / The Museum Science Press also publish:

Adansonia, Geodiversitas, Zoosystema, Anthropozoologica, European Journal of Taxonomy, Naturae, Cryptogamie sous-sections Algologie, Bryologie, Mycologie.

L'Académie des sciences publie aussi / The Académie des sciences also publishes:

Comptes Rendus Mathématique, Comptes Rendus Physique, Comptes Rendus Mécanique, Comptes Rendus Chimie, Comptes Rendus Géoscience, Comptes Rendus Biologies.

Diffusion - Publications scientifiques Muséum national d'Histoire naturelle

CP 41 - 57 rue Cuvier F-75231 Paris cedex 05 (France)

Tél. : 33 (0)1 40794805 / Fax: 33 (0)1 40793840

diff.pub@mnhn.fr / https://sciencepress.mnhn.f

Académie des sciences, Institut de France, 23 quai de Conti, 75006 Paris.

(C) Publications scientifiques du Muséum national d'Histoire naturelle / @ Académie des sciences, Paris, 2021

ISSN (imprimé / print): 1631-0683/ ISSN (électronique / electronic): 1777-571X 


\section{Tetraodontiformes (Osteichthyes, Actinopterygii) from the Miocene of Argentina: with the southernmost record of fossil Tetraodontidae}

Soledad GOUIRIC-CAVALLI

División Paleontología Vertebrados, Museo de La Plata, Facultad de Ciencias Naturales y Museo, Universidad Nacional de La Plata, Paseo del Bosque s/n,

B1900FWA, La Plata, Buenos Aires (Argentina) and CONICET, Consejo de Investigaciones Científicas y Técnicas, Godoy Cruz 2290

C1425FQB, Ciudad Autónoma de Buenos Aires (Argentina) sgouiric@fcnym.unlp.edu.ar (corresponding author)

Maria de las Mercedes AZPELICUETA División Zoología Vertebrados Museo de La Plata, Facultad de Ciencias Naturales y Museo, Universidad Nacional de La Plata, Paseo del Bosque s/n, B1900FWA, La Plata, Buenos Aires (Argentina) azpeli@fcnym.unlp.edu.ar

Alberto L. CIONE División Paleontología Vertebrados, Museo de La Plata, Facultad de Ciencias Naturales y Museo, Universidad Nacional de La Plata, Paseo del Bosque s/n, B1900FWA, La Plata, Buenos Aires (Argentina) acione@fcnym.unlp.edu.ar

Submitted on 4 May 2020 | Accepted on 2 June 2020 | Published on 23 June 2021

urn:Isid:zoobank.org:pub:543EDC00-9D21-4801-9457-18135FAE2D10

Gouiric-Cavalli S., Azpelicueta M. M. \& Cione A. L. 2021. - Tetraodontiformes (Osteichthyes, Actinopterygii) from the Miocene of Argentina: with the southernmost record of fossil Tetraodontidae. Comptes Rendus Palevol 20 (27): 585-596. https://doi.org/10.5852/cr-palevol2021v20a27

\section{ABSTRACT}

Teleostean evolution produced enormous variation in tooth morphology. This variation is related to the exploration and exploitation of very diverse dietary niches. Among extant fishes, several taxa of the order Tetraodontiformes (e.g. pufferfishes, porcupinefishes and ocean sunfishes) have evolved highly specialized beak-like tooth structures. Here we provide the first description of tetraodontiform crushing beaks from Argentina. A single complete premaxillary beak recovered from the early Miocene Gaiman Formation in Chubut Province is assigned to Molidae based on its premaxillaries being completely fused to one another along the midline, general morphology, and size. Moreover, due to 
KEY WORDS

Beaked-dentition,

Paraná Formation,

Gaiman Formation, Southern Hemisphere.

MOTS CLÉS

Denture en bec, formation Paraná, formation Gaiman, hémisphère sud. the putative presence of rows of teeth fused to the thick and massive bone structure, the specimen might belong to the genus Ranzania Nardo, 1840. Several premaxillary beaks recovered in the late Miocene Paraná Formation of Entre Ríos Province are assigned to Tetraodontidae Bonaparte, 1832 based on the presence of long, slender, rod-like, and parallel dental units; premaxillae not fused in the midline but articulated by interlocking emarginations, and a few small and one large trituration dental units. Argentinian tetraodontiform fishes inhabited the warm-temperate Paranense and Patagoniense Seas (marine transgressions developed in southeastern South America) during the early-late Miocene; these specimens are the southernmost fossil record of the group worldwide. Tetraodontiforms are extremely rare in recent Argentinian marine waters. The new fossil records agree with the higher sea water surface temperatures suggested both locally and worldwide for the Miocene.

\section{RÉSUMÉ}

Tétraodontiformes (Osteichthyes, Actinopterygii) du Miocène d'Argentine : avec la plus méridionale des occurrences de Tetraodontidae fossiles.

L'évolution des Téléostéens a produit une variation énorme dans la morphologie dentaire. Cette variation est à mettre en relation avec l'exploration et l'exploitation de niches alimentaires très diverses. Parmi les poissons actuels, plusieurs familles de l'ordre des Tétraodontiformes (à savoir poissons globe, poissons porc-épic et poissons lune) ont des structures dentaires très évoluées, en forme de bec. Nous donnons ici la première description de becs triturants de tétraodontiformes d'Argentine. Un unique bec complet prémaxillaire du Miocène inférieur à moyen de la formation Gaiman dans la province de Chubut a été assigné aux Molidae, sur la base de prémaxillaires complètement fusionnés l'un dans l'autre le long de la ligne médiane, de la morphologie et de la taille. De plus, en raison de la présence présumée de rangées de dents amalgamées à la structure osseuse massive et épaisse, le spécimen pourrait appartenir au genre Ranzania Nardo, 1840. Plusieurs becs prémaxillaires récoltés dans le Miocène moyen-supérieur de la formation Paraná dans la province d'Entre Rios sont assignés aux Tétraodontidae Bonaparte, 1832 sur la base de la présence d'unités dentaires parallèles, longues et minces en forme de baguette; de prémaxillaires non fusionnés dans la ligne médiane mais articulés par des émarginations imbriquées, et quelques petites et une grande unités dentaires triturantes. Les poissons tétraodontiformes argentins ont vécu dans les mers Paranense et Patagoniense tempéréeschaudes (transgressions marines développées dans le sud-est de l'Amérique du Sud); ces spécimens constituent le signalement de ce groupe fossile le plus méridional au monde. Les Tétraodontiformes sont extrêmement rares dans les eaux marines récentes d'Argentine. Les nouveaux signalements fossiles plaident en faveur de plus hautes températures des eaux marines superficielles, suggérées à la fois localement et mondialement au Miocène.

\section{INTRODUCTION}

Bony-fish dentition shows a remarkable variability in morphology (e.g. Berkovitz \& Shellis 2017). Also, the development of teeth occurs in several different ways (Huysseune \& Sire 1992; Trapani 2001; Sire et al. 2002; Berkovitz \& Shellis 2017). Bonyfish dentition has a first generation of tooth germs originating directly from the oral epithelium (e.g. Sire et al. 2002). In some osteichthyans taxa, the origin of teeth has been related to the resorption cavities in the cartilage (Huysseune \& Sire 1992). The origin of the replacement tooth generations varies and might be extraosseous - in the soft tissue outside the bone to which posteriorly attach - or intraosseous - in sockets within the bone (Trapani 2001; Berkovitz \& Shellis 2017).

Crushing dentitions appeared early in the fossil record of Osteichthyes (Moya-Smith \& Campbell 1987; Smith 1988; Kriwet 2005; Poyato-Ariza 2005; Johanson \& Smith 2005; Wu et al. 2013). Hitherto, one of the most specialized crushing type dentitions appears in living Tetraodontiformes - a group which includes the porcupinefishes (Diodontidae Bonaparte, 1838), pufferfishes (Tetraodontidae Bonaparte, 1832), ocean sunfishes (Molidae Ranzani, 1837), filefishes (Monacanthidae Nardo, 1842), boxfishes (Ostraciidae Rafinesque, 1810), tigerfishes (Balistidae Rafinesque, 1810), and several other taxa (Tyler 1980; Santini \& Tyler 2003; Close et al. 2016; Bannikov et al. 2017). The beak-like dentition of several tetraodontids (i.e., porcupinefishes, pufferfishes, ocean, and sunfishes) is a complex of bony and dental tissues with teeth that form intraosseusly (Trapani 2001). Replacement teeth in tetraodontids develop beneath the functional teeth and, when resorption occurs, they move into the newly opened area, thus completing their growth (Fraser et al. 2012).

Tetraodontiformes has a long-known fossil record dating back to the Late Cretaceous, and are best-known in the Eocene and Miocene (Tyler \& Santini 2002; Santini \& Tyler 2003; Aguilera et al. 2017 and references therein). Late Cretaceous Tetraodontifomes have no evident teeth in their jaws (Tyler \& Sorbini 1996; Santini \& Tyler 2003). 
However, Tetraodontoidei or Gymnodontes (i.e., Triodontidae Bleeker, 1859, Tetraodontidae, Molidae, Diodontidae, and Avitoplectidae Bemis, Tyler, Bemis, Kumar, Rana \& Smith, 2017) have beak-dentitions originating by the fusion of teeth and their jaw bones (Tyler 1980; Andreucci \& Britski 1982). The fossil record of Tetraodontoidei goes back to the Eocene (Tyler 1980; Tyler \& Bannikov 1992; Tyler \& Santini 2002; Santini \& Tyler 2003).

In South America, fossil Tetraodontoidei have been reported from the Miocene-Pliocene of Perú (Muizon \& Devries 1985), and the Miocene of Argentina, Brazil, Colombia, and Venezuela (Woodward 1901; Cione et al. 2011; Aguilera et al. 2017). An isolated dental plate has been reported in the Late Cretaceous of Brazil (Gallo et al. 2009). However, the age of that finding remains doubtful (see discussion in Dornburg et al. 2014 and Bannikov et al. 2017).

Considering the Argentinian specimens, Woodward (1901: 576) assigned with doubts a "portion of typical jaw" to the genus Mola Koelreuter, 1776 (Orthragoriscus Bloch \& Schneider, 1801). Woodward mentioned that the material comes from the Patagonian Formation which crops out in Chubut Province. The rocks exposed in that area are formally known as Gaiman and Chenque formations and are considered early Miocene in age (Bertels 1970, see also Parras \& Cuitiño 2021). That and other material, reported later (Cione 1988; Cione \& Azpelicueta 2002; Cione et al. 2011) was never formally described.

Here we provide a qualitative study of beaked-dentitions found in the early Miocene Gaiman Formation (Chubut Province, Patagonia Argentina) and the late Miocene of Paraná Formation (Entre Ríos Province, North Eastern Argentina). We compare these records with those of other parts of the globe.

\section{MATERIAL AND METHODS}

The material studied herein consists of one upper beak (MLP 86-II-22-1) recovered in the Gaiman Formation and several partially preserved upper beaks (CICYTTP-Pv-P-1-323, CICYTTP-Pv-P-1-426, CICYTTP-Pv-P-1-543, CICYTTPPv-P-1-569, CICYTTP-Pv-P-1-631, CICYTTP-Pv-P-1-724) recovered in several independent expeditions made by one of the authors (ALC) to the fossiliferous units of the Paraná Formation at La Juanita and Toma Vieja localities (Fig. 1). The specimens are housed at the Vertebrate Paleontology collection of the División Paleontología Vertebrados, Museo de La Plata (MLP) and in the paleontological collections of the Centro de Investigaciones Científicas y Transferencia de Tecnología a la Producción de Diamante (CICYTTP), Entre Ríos, Argentina.

The material was studied under binocular microscope Zeiss Stemi 2000C and SEM (Scanning Electron Microscope) FEI ESEM Quanta 200 equipped with electron source from a tungsten filament with $200 \mathrm{~V}-30 \mathrm{kV}$ accelerating voltage. The samples were analyzed under Low Vacuum mode (LoVac) with a precision of 0.1 to 1 Torr, without metalizing. Secondary electron detectors, were used looking for a high topographic

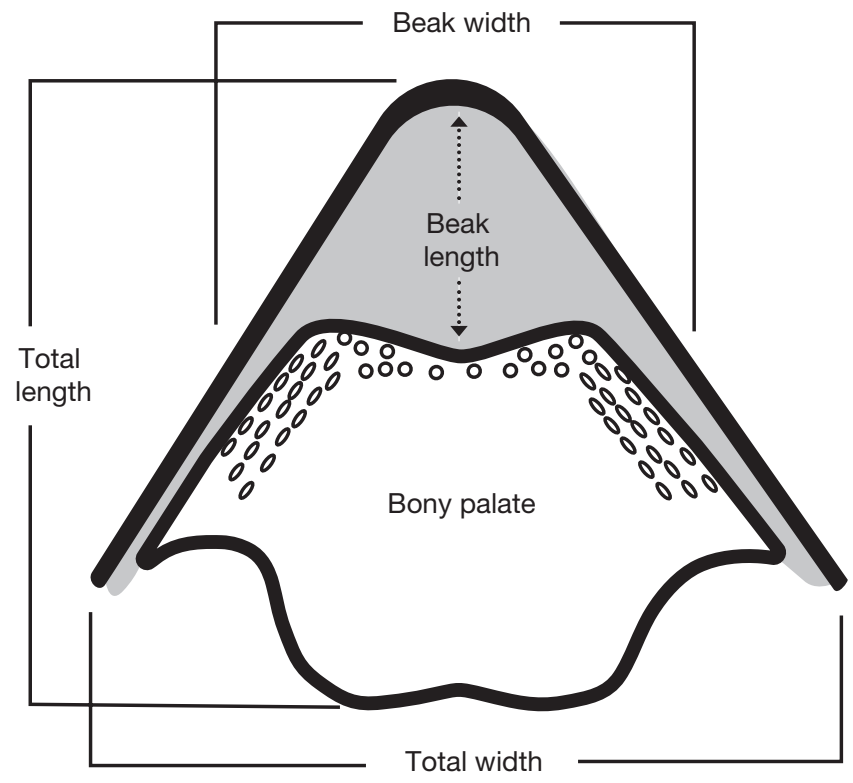

FIG. 1. - Beak meristics on molid according to Weems (1985).

contrast image of the examined surface. Backscattered electrons (BE) detectors of two sectors BSED were employed in order to observe variations in the atomic number $(\mathrm{Z})$ of the elements detected on surface. Heterogeneity of the sample is expressed in the image through different gray tonalities depending on the atomic number.

Descriptive terminology (Fig. 2) follows Tyler (1980), Weems (1985) and Aguilera et al. (2017). Also, an extensive review of the literature was made in order to compare the specimens. Material from extant species housed at Sección de Zoología Vertebrados, Museo de La Plata (MLP) and Cátedra de Ictiología, Facultad de Ciencias Naturales y Museo (FCNyM) was used for comparison. Meristics follows Weems (1985).

\section{GEOLOGICAL SETTING}

The Gaiman and Paraná formations were deposited during the Miocene as consequence of a marine transgression from the Atlantic that covered most of the eastern regions of South America, especially Argentina, Uruguay, Brazil, and Bolivia. As a consequence of this event, the so-called Entrerriense or Paranense and Patagoniense seas develops.

\section{PARANÁ Formation}

The Paraná Formation represents a widespread marine deposits of the Atlantic Ocean in South America, being part of the so called Entrerriense or Paranense Sea. During the middle and late Miocene, this sea covered most of the Chaco-Paraná Basin and eastern Patagonia to the northern portion of the Sierras Subandinas and the north-western Sierras Pampeanas in Argentina, reaching as far north and east as Bolivia, Paraguay, western Uruguay, and southern Brazil (Hernández et al. 2005; Vélez-Juarbe et al. 2012 and references therein). The age of the Paraná Formation has been largely debated on 
the basis mainly of different biostratigraphic interpretations regarding its included invertebrate fauna, ranging from middle (e.g. Aceñolaza 2000; del Río 2000; Aceñolaza \& Aceñolaza 2000) to late Miocene (e.g. Frenguelli 1920; Camacho 1967; Aceñolaza 1976; Zabert 1978; Cione et al. 2000). However, recent studies supported by new paleontological evidence and radioisotope dating tend to assign at least the outcropping beds to the late Miocene (Pérez 2013; del Río et al. 2018).

\section{GAIMAN FORMATION}

The Gaiman Formation was deposited during the marine Patagoniense transgression. To date no isotopic data are available for Gaiman Formation and an early Miocene age is supported by correlations with other dated basins and formations, fossils, and palinomorphs (Palazzesi et al. 2006; Cione et al. 2011; Parras et al. 2012; Parras \& Cuitińo 2021).

\section{SYSTEMATIC PALEONTOLOGY}

\author{
Class ACTINOPTERYGII Cope, 1887 \\ Infra-class TELEOSTEI Müller, 1844 \\ Order TETRAODONTIFORMES Regan, 1929 \\ Family MOLIDAE Ranzani, 1839 \\ Genus Ranzania Nardo, 1840
}

\section{cf. Ranzania sp.}

Ranzania sp. - Nardo 1840: 111.

Molidae indet. - Cione 1988: 447. — Cione \& Azpelicueta 2002: 370.

molid teleost - Cione et al. 2011: 429.

Familial STRATIGRAPHiC RANGE. - Upper Eocene to Recent (Tyler \& Bannikov 1992).

MATERIAL REFERRED. - MLP 86-II-22-1, a beak formed by fused premaxillaries.

GeneriC Diagnosis. - Modified from Weems (1985). Endoskeleton mainly cartilaginous. Body covered by dermal polygonal plates. Beak formed by the fusion of both premaxillaries in the upper jaw and both dentaries in the lower jaw. Upper beak posteriorly containing rows or patches of teeth fused against a thick mass of bone overlying roof of mouth.

GEOLOGY AND STRATIGRAPHY. - The material was recovered at the Gaiman Formation, lower Miocene, Chubut Province, Patagonia Argentina (Parras \& Cuitiño 2021; Fig. 2).

\section{DESCRIPTION}

The preserved upper jaw is thick and wide (Fig. 3) and has two portions: a well-developed and sharp beaked portion and a bony palate. In lateral view the beak and the bony palate form an obtuse angle. The preserved total length of the upper jaw is $c .40 \mathrm{~mm}$, the total wide is $c .50 \mathrm{~mm}$, and the beak length is $c .12 \mathrm{~mm}$. The external and lingual surfaces of the beaked portion have a shiny tissue that we interpret as enamel (Fig. 3D). The bony external surface of the upper jaw is striated (grooved or creased). Some sections of the upper jaw show its internal core which has a structure composed of "tubules" that might be vascular canals of osteodentine (Fig. 3). This tubular structure is also evidenced on the surface of the specimen studied herein due to post-mortem wear (Fig. 3A, C). In lingual view, the beak portion is slightly concave and has almost the same width along the biting margin (Fig. 3B). The bony palate is not very well preserved and is triangular. Caudad, some conical structures are recognized; we interprete those structures as poorly preserved teeth (Fig. 3B). Some of these teeth might have enamel. Thus, the caudad region has at least three irregular rows and is clearly differentiated from the biting portion (Fig. 3B).

\section{TAXONOMIC REMARKS}

Members of the family Molidae are known as ocean sunfishes. Molids have an extreme complex jaw formed by the fusion of bone and dental tissues (Tyler 1980). Premaxillaries and dentaries are indistinguishably fused in the midline (Tyler 1980). Recent molids are represented by three genera and five species Mola mola Linnaeus, 1758; $M$. alexandrini (Ranzani, 1839); M. tecta Nyegaard, Sawai, Gemmell, Gillum, Loneragan, Yamanoue \& Stewart, 2017, Masturus lanceolatus (Liénard, 1840); and Ranzania leavis Pennant, 1776.

The fossil record of molids is patchy since their endoskeletons are largely cartilaginous and their pelagic habitat is not conducive to fossilization. Thus, the family is mainly represented by beaked dentitions and dermal scale plates (Tyler $\&$ Santini 2002). To date, fossil molids are represented by four genera: Eomola Tyler \& Bannikov, 1992; Austromola Gregorova, Schultz, Harzhauser, Kroh \& Corić, 2009; Ranzania Nardo, 1840; and Mola Koelreuter, 1776.

The beak described herein was previously reported as an indeterminate Molidae (Cione 1988; Cione \& Azpelicueta 2002; Cione et al. 2011) but it was not formally described. It is assigned to Molidae because of the presence of completely fused premaxillaries, general morphology, and size. Moreover, based on the putative presence of rows of teeth fused to the thick and massive bone structure, the specimen might belong to the genus Ranzania. However, more specimens are needed to provide a precise taxonomic assignment.

Molid fishes occur in tropical and temperate waters around the world, being solitary and pelagic. In South America, the southernmost record of extant molids corresponds to Mola mola Linnaeus, 1758 recovered in Solano Bay $40 \mathrm{~km}$ north of Comodoro Rivadavia city in Chubut Province (Aramburu 1957) and the southernmost extant record of Ranzania laevis Pennant, 1776 is New Zealand (Smith et al. 2010). Fossil specimens of the genus Ranzania have been recovered from the lower Miocene of North Carolina (Weems 1985), middle Miocene of Italy, (Carnevale 2005), Japan (Uyeno \& Sakamoto 1994), and late Miocene (Messinian) of northwestern of Argelia (Carnevale \& Santini 2007).

Family TetraOdOnTIDAE Bonaparte, 1832

Familial STRatigraphic RAnge. - Middle Eocene to Recent (Tyler \& Santini 2002). 


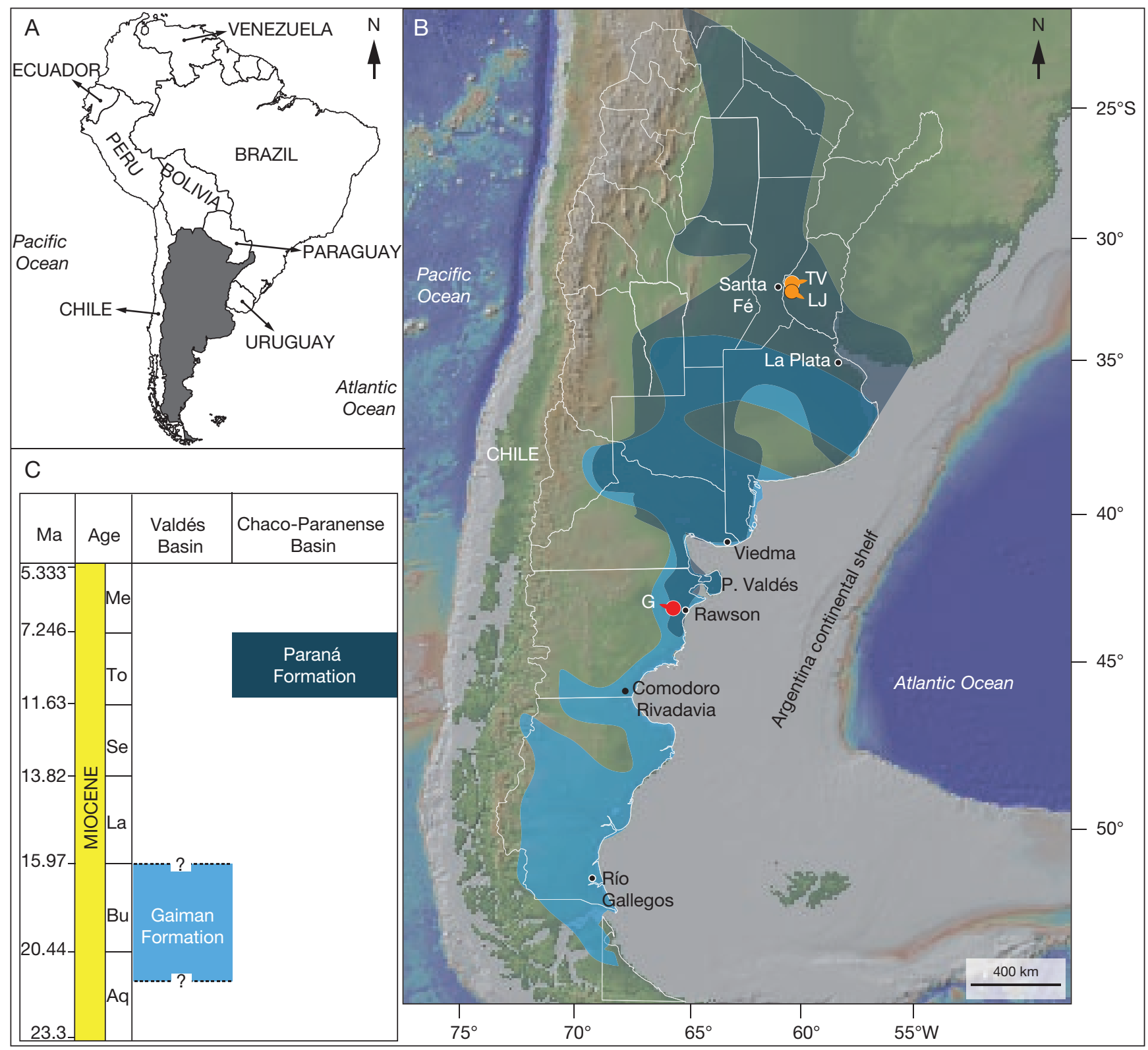

FIG. 2. - Location map indicating where tetraodontiform specimens have been recovered: A, geographic location, Argentina is in gray; $\mathbf{B}$, paleogeography of the Miocene Paranense (dark blue) and Patagoniense (light blue) marine deposits; orange circles indicate tetraodontid beaks recovered from the Paraná Formation in Entre Ríos Province; red circle indicates the molid beak recovered from Gaiman Formation in Chubut Province; $\mathbf{C}$, chronostratigraphic chart of deposits of Gaiman (light blue indicates Patagoniense) and Paraná (dark blue indicates Paranense) formations in eastern Patagonia and NEA (northeastern Argentina). Dotted lines and question marks indicate unknown radiometric ages for Gaiman Formation. Data on marine deposits and ages modified from Cuitiño et al. (2017), Pérez (2013) and Parras \& Cuitiño (2021). Global Multi-Resolution Topography base map from GeoMapApp` (Ryan et al. 2009). Abbreviations: Aq, Aquitanian; Bu, Burdigalian; G, Gaiman; La, Langhian; LJ, La Juanita; Me, Messinian; Se, Serravalian; To, Tortonian; TV, Toma Vieja.

MATERIAL REFERRED. - CICYTTP-Pv-P-1-323, right almost complete premaxilla, CICYTTP-Pv-P-1-426, incomplete right premaxilla represented by the biting portion, CICYTTP-Pv-P-1-569, incomplete right premaxilla represented by the biting portion, CICYTTPPv-P-1-543, fragmentary biting portion; CICYTTP-Pv-P-1-631, fragmentary left premaxilla with biting portion; CICYTTP-PvP-1-724, two fragments of biting portion with rod-like dental units and a fragmentary left premaxilla biting portion.

Geology and STRATigraphy. - Uppermost levels of the Paraná Formation, upper Miocene (Tortonian-Messinian), Entre Ríos Province, Argentina (del Río et al. 2018; Fig. 2). Most of the specimens were collected at La Juanita locality (level 1) and CICYTTP-PvP-1-323 was recovered at Toma Vieja locality (level 3).

\section{DESCRIPTION}

Massive crushing plates formed by the articulation of premaxillaries. In medial or symphyseal view, the articulation between both premaxillary is composed of four to six welldeveloped projections of each premaxillary bone (Figs 4; 5C). The projections at the middle section of the symphysis seem to be transversally longer than those of Lagocephalus Swainson, 1839 (see Tyler 1980: 269). In occlusal view, the premaxillary has an internal cavity containing the pulp cavity of the long, rod-like teeth. The teeth lie parallel to the anterior edge of the premaxillary bone. There are four to twelve replacement teeth (Fig. 4C) and only two (possibly 


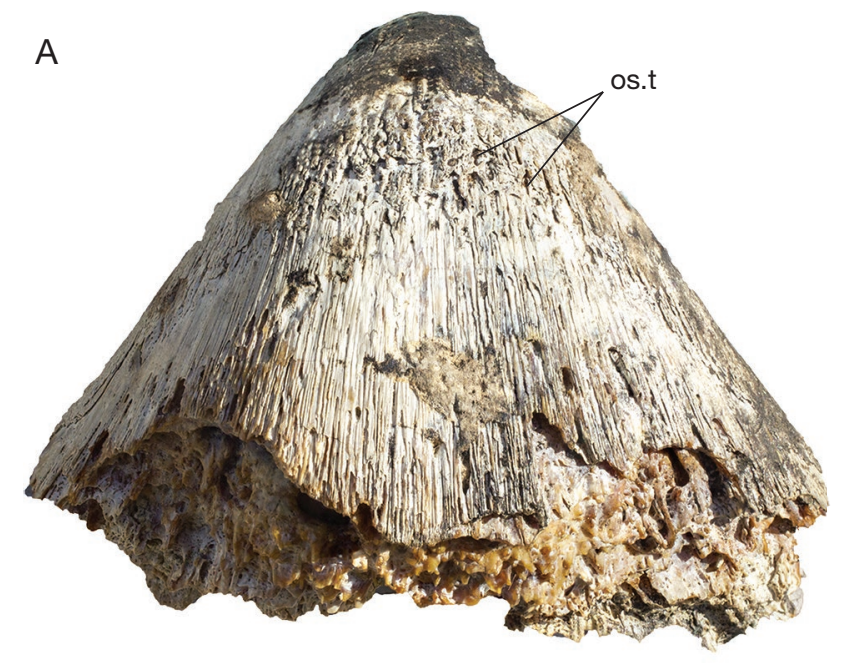

C

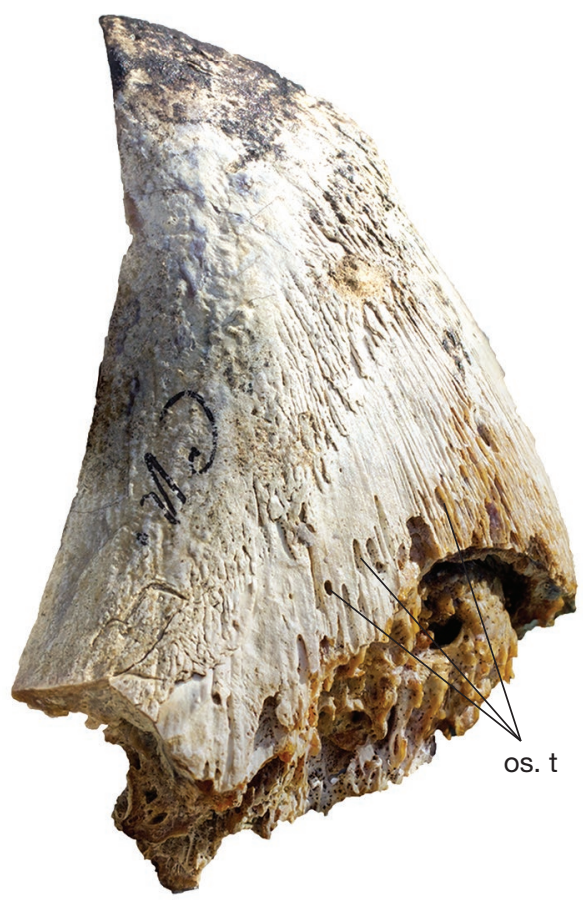

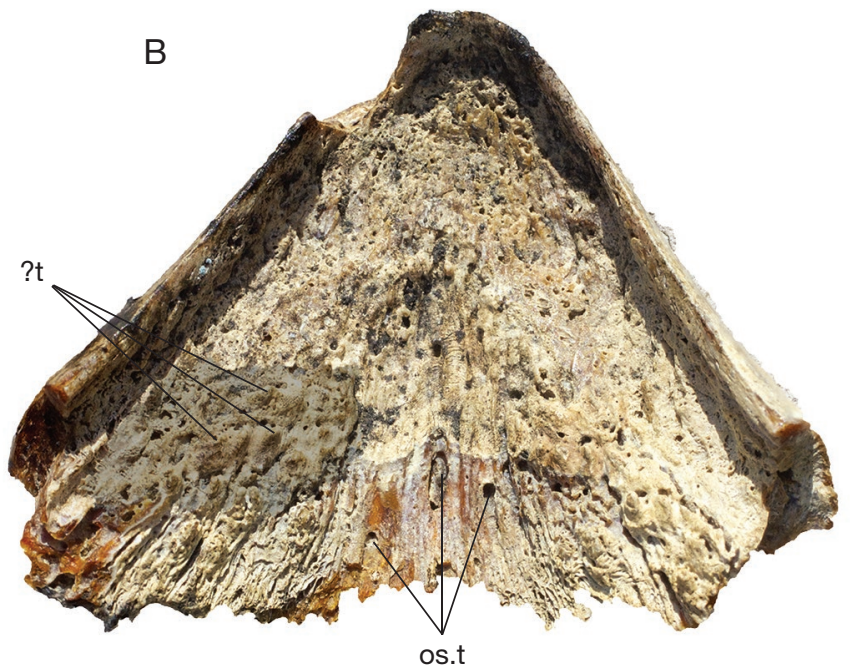

D

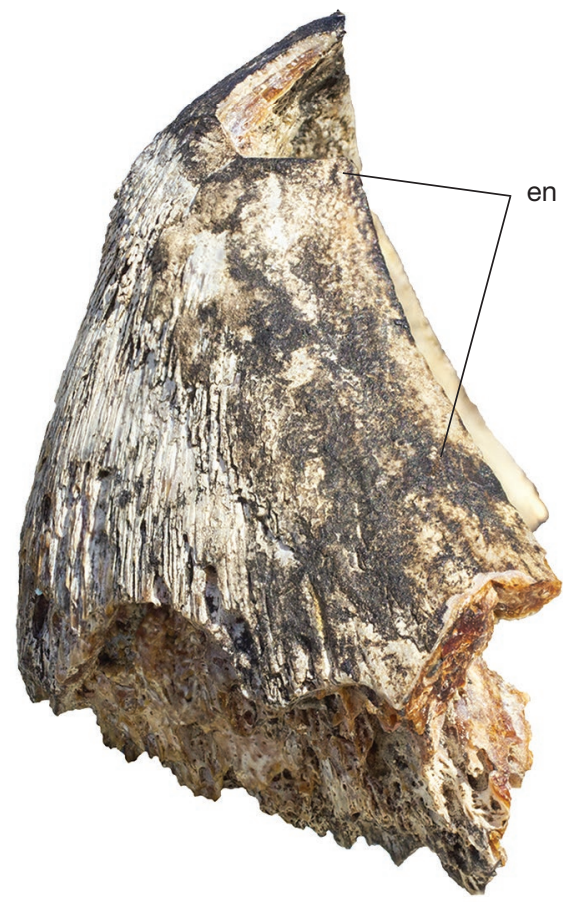

FIG. 3. - MLP 86-II-22-1, cf. Ranzania Nardo, 1840 beak dentition: A, dorsal view; B, lingual view; C, left view; D, right view. Abbreviations: en, enamel; os.t, osteodentine tubules; $\mathbf{t}$, teeth. Scale bars: $1 \mathrm{~cm}$.

three) of them are visible at the premaxillary biting edge. On the ventral surface, three more or less blunt, elongated, and sigmoidal teeth lie in shallow sockets arranged in a longitudinal row just lateral to the medial edge (Figs 4B, $\mathrm{D} ; 5 \mathrm{E})$. The anterior tooth is at least half of the length of remaining teeth (Figs 4B, D; 5A, C, F); it is more or less triangular with a tall anterior vertex close to symphysis. The teeth are ornamented with faint lines.

In lingual view, the beak is formed by parallel dental units (Fig. 4B, D). These units are arranged in two groups: long (nine to ten) and short (three or four). The dental units are shorter near the symphysis and considerably longer caudad (Fig. 4B, D). CICYTTP.PV.P.1. 569 in labial view shows long dental units intercalated by small units (Fig. 4D). CICYTTP.
PV.P.1. 426 in labial view shows the notches of articulation among premaxillae (Fig. 4E).

Since there are only three well-preserved beaks and the histology of beaks in Tetraodontidae is not fully understood, we preferred not performing histological sections. However, because some of the material from the Paraná Formation show different degrees of wear, we briefly describe it. Wear has its maximum development in the dental units near the symphysis, which decreases backward. In the beaks CICYTTPPV-P-1-323 and CICYTTP-PV-P-1-426 the biting portions have the maximum degree of wear (Fig. 5A-D). However, replacement dental units in CICYTTP-PV-P-1-323 do not show wear but in CICYTTP-PV-P-1-426 the same units have well-developed wear. In CICYTTP-PV-P-1-569 the 
A

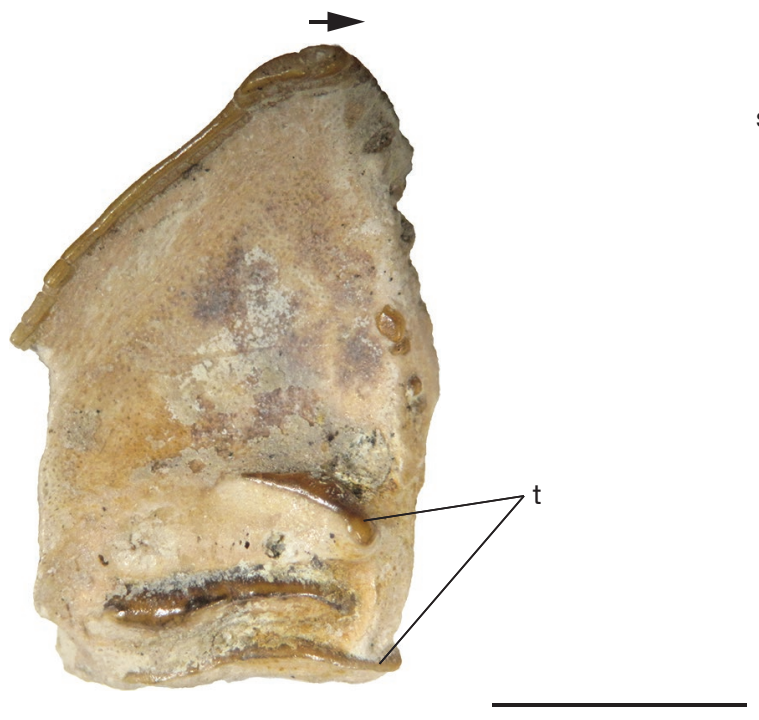

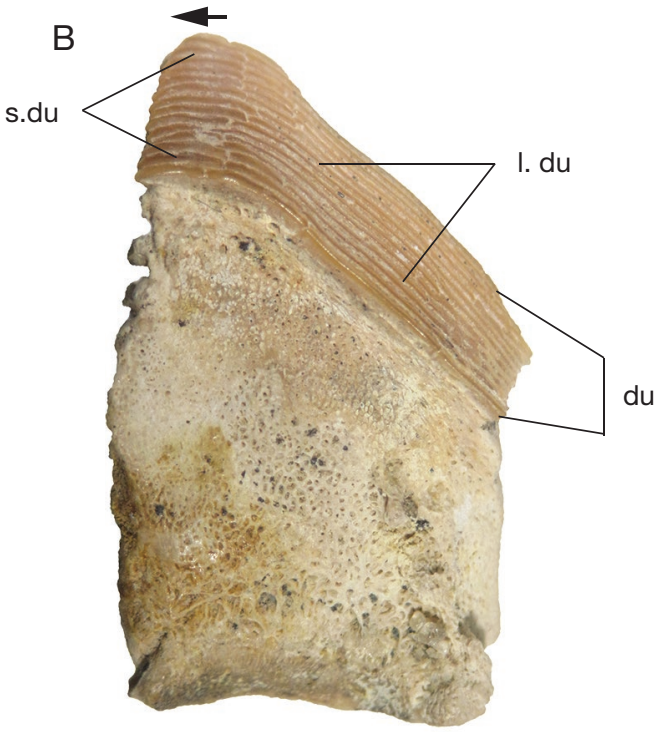

D

C
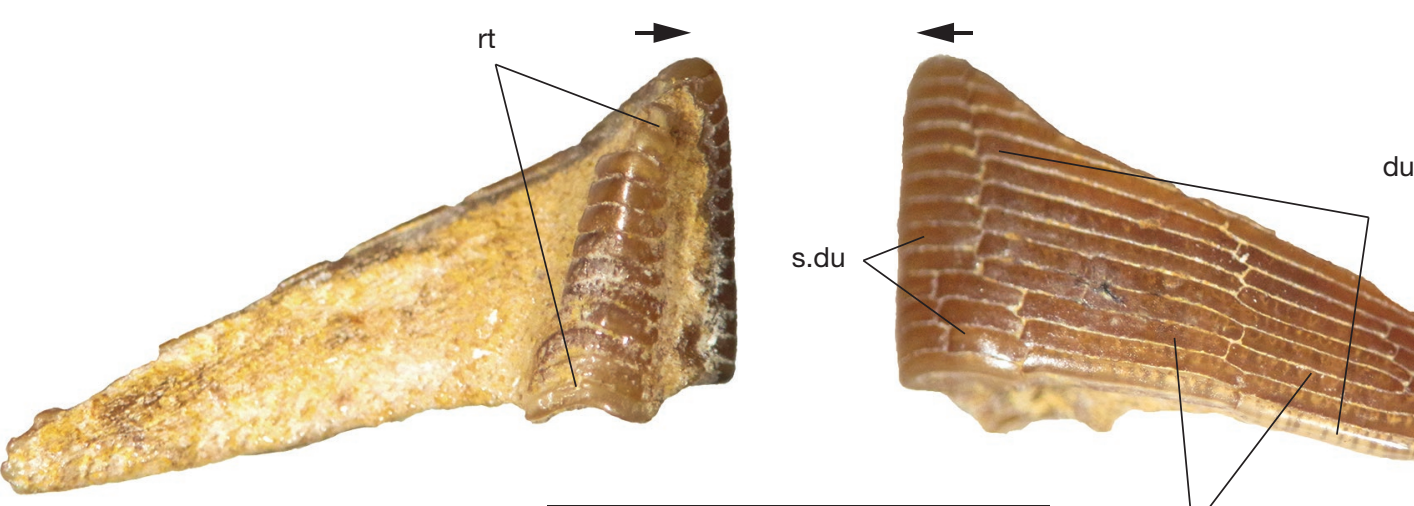

du

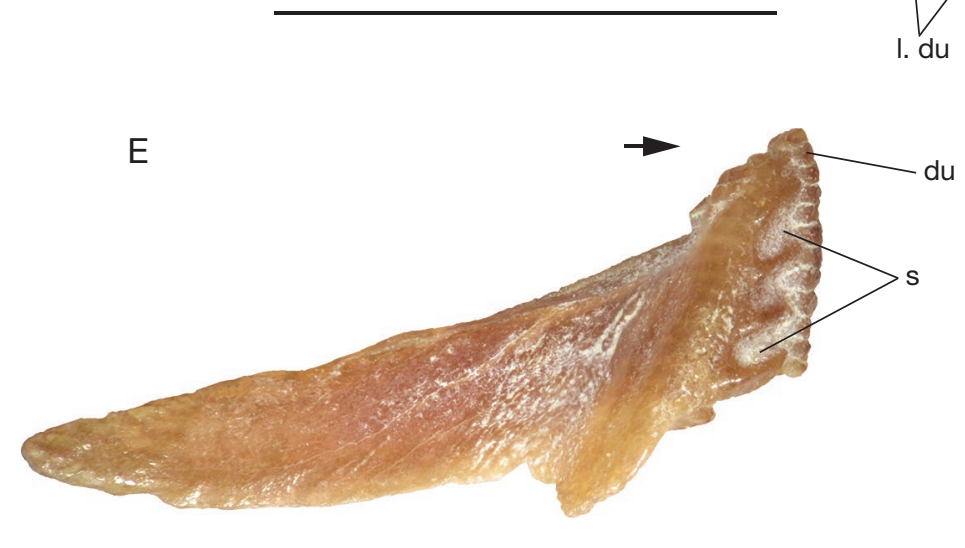

FIG. 4. - Tetraodontidae indet. premaxillary beak dentitions: A, B, CICYTTP.PV.P.1.323: A, lingual view; B, dorsal view; C, D, CICYTTP.PV.P.1. 569: C, lingual view; D, labial view; E, CICYTTP.PV.P.1. 426 in lingual view. Abbreviations: du, dental units; I. du, large or long dental units; rt, replacement teeth; s, symphysis; s. du, small or short dental units; t, teeth. Black arrow indicates symphysis. Scale bars: A-D, 5 mm; E, 10 mm.

beak does not show wear and the dental units forming the cutting edge are antero-posteriorly compressed (Fig. 5E, F). Since CICYTTP-PV-P-1-569 is the smallest specimen, we hypothesize that it is a young adult and that wear is caused by biting hard organisms like coral or gastropods as in many extant tetraodontiforms.

\section{TAXONOMIC REMARKS}

Within the Tetraodontiformes, we assign the Paraná Formation specimens to the tetraodontoids or gymnodontids because they have crushing beaks composed of upper and lower jaw bones fused with teeth which characterizes this beak-toothed group. Within the Tetraodontoidei, the material belongs in 

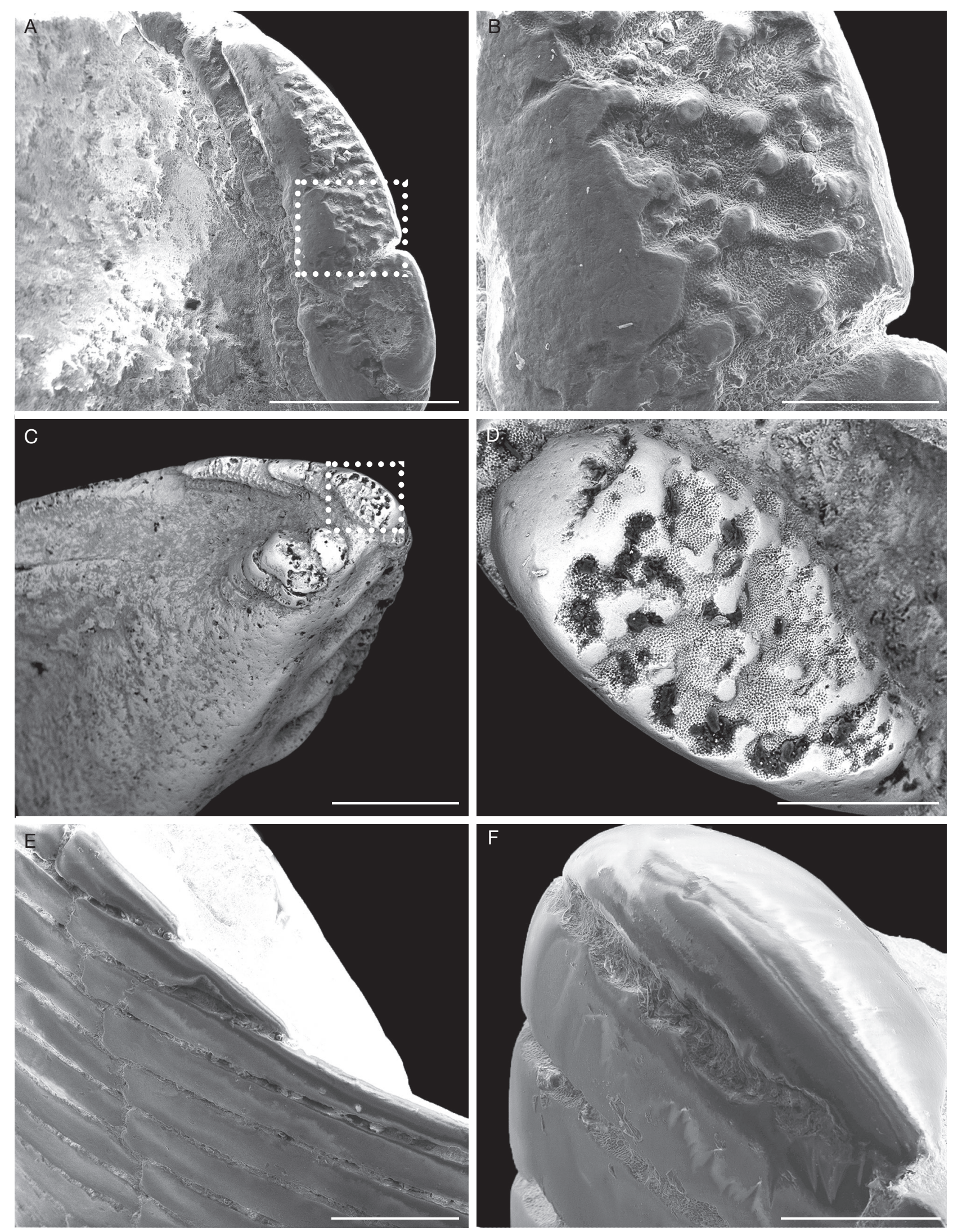

FIG. 5. - Tetraodontidae indet. premaxillary beak dentitions under SEM: A, B, CICYTTP.PV.P.1.323 lingual view of a portion of the beak and bone of an adult specimen: A, dental units and bone; B, close up to show the wear in the anterior dental units; C, D, CICYTTP.PV.P.1.426: C, backscattered image showing a general view of the dental units; D, backscattered image showing a close up to show the wear over life in the anterior dental unit; E, F, CICYTTP.PV.P.1.569, young adult specimen: $\mathbf{E}$, general view of the dental units, note the non-wearing enamel; $\mathbf{F}$, close up of the anterior dental unit of $\mathbf{E}$, note the sharp edge of the anterior dental unit. Scale bars: A, C, $1 \mathrm{~mm}$; B, D, F, $200 \mu \mathrm{m}$; E, $500 \mu \mathrm{m}$. 
the family Tetraodontidae sensu Tyler (1980) based on the presence of long, slender, rod-like, and parallel dental units (Fig. 4); premaxillae not fused in the midline but articulated by interlocking emarginations; few small and one large trituration dental units present (CICYTTP-Pv-P-1-323; Fig. 4). According with Tyler (1980) the subfamily Tetraodontinae is the only one with trituration dental units.

We compare the Miocene material from Argentina with those of the family Tetraodontidae in which premaxillae were described in detail (see Tyler 1980) and also with recent material from the ichthyological collection of the La Plata Museum. Since the Argentinian material has crushing dental units which are characteristic of Tetraodontinae it is possible that the specimens belong to this family. However, a more detailed study is needed.

The Argentinian material differs from Lagocephalus in having more replacement dental units (12) vs five to ten and interlocking emarginations between premaxillae four to five vs twelve. It presents also three trituration dental units vs two to six; however, we cannot be certain of this feature since we only have one specimen with trituration dental units (i.e., CICYTTP-Pv-P-1-323; Fig. 4A, B). The Argentinian specimens differ from Canthigaster Swainson, 1839 by having trituration dental units. Also, Canthigaster has more replacement teeth (15 to 20) and more interlocking emarginations (15 to 20). Argentinian specimens differs form those reported from the Miocene of Angola (Antunes 1978; Antunes et al. 1981) because African specimenes have more parallel long dental units (c. 20).

\section{DISCUSSION}

Tetraodontiformes is a primarily marine actinopterygian group that shows a widespread distribution with a remarkable body plan variety, including the porcupinefishes (Diodontidae), pufferfishes (Diodontidae), ocean sunfishes (Molidae), boxfishes (Ostraciidae), and tigerfishes (Balistidae). The Tetraodontiformes fossil record dates back to the Late Cretaceous (Tyler \& Sorbini 1996; Tyler \& Santini 2002; Arcila et al. 2015; Close et al. 2016; Arcila \& Tyler 2017; Bannikov et al. 2017). All Tetraodontiformes have a specialized diet and most of them feed on molluscs (i.e., bivalves and gastropods). However, molid fishes are highly specialized to feed on jellyfishes, although they also can feed on squids and small actinopterygians (Berkovitz \& Shellis 2017).

Cenozoic marine outcrops are exposed at the southwestern Atlantic coasts of southeastern of Brazil to southern Argentina (del Río et al. 2018). The Patagoniense Sea (late Oligocene to early Miocene), which was located at the eastern of Patagonia in southern South America, represents the oldest major flooding event by the Atlantic Ocean. The outcrops include four formations known as Monte León, Carmen Silva, Chenque, and Gaiman (Cuitiño et al. 2017). The youngest Atlantic Ocean flooding is known as the Paranense or Entrerriense Sea, which occurred mainly during the late Miocene and comprises units in Uruguay (i.e., Camacho Formation) and Argentina (i.e., Paraná Formation) in Entre Ríos Province, "Entrerriense Beds" in Buenos Aires Province, Balneario La Lobería facies of the Río Negro Formation in Río Negro Province and Puerto Madryn Formation in Chubut Province (see del Río et al. 2018 and the references therein).

The Paranense units are known by an extremely diverse molluscan fauna (del Río 1991; del Río et al. 2018) and other hard invertebrates (i.e., poriferans, bryozoans, brachiopods, arthopods, and echinoderms) (Pérez et al. 2013). At Gaiman and Paraná formations, the ichthyofauna is characterized by the presence of several chondrichthyans and also a few teleosteans (Cione in Scasso \& Castro 1999; Cione \& Azpelicueta 2002; Cione et al. 2011, 2013). This proportion is certainly due to taphonomic reasons (Cione et al. 2013).

The specimens described herein represent the first formal description of fossil Tetraodontiformes from Argentina. The new descriptions presented herein are relevant in terms of the distribution of Tetraodontiformes during the Miocene in the Southern Hemisphere, being the southernmost record of fossil Tetraodontiformes worldwide. The specimens recovered at Paraná Formation are assigned to Tetraodontidae; other Southern Hemisphere records are isolated and fragmentary dentitions from the Miocene of Angola (Antunes 1978; Antunes et al. 1981). Considering the available source of food - mainly molluscan and gastropods - but also annelids, echinoderms, and brachiopods (Pérez et al. 2013), we consider that tetraodontid actinopterygians lived and fed in the shallow temperate warm waters near the coastline of the present Entre Ríos Province (e.g. Cione et al. 2013). This is also in agreement with previous hypotheses about global and local temperatures during the Miocene (see Zachos et al. 2001; Cione et al. 2013).

The molid records of the Gaiman Formation (Chubut Province) could be random findings. Recent molid records in Patagonia are extremely rare and those actinopterygians are captured accidentally in trawler fishing (e.g. di Giácomo et al. 2015). However, since molids are usually pelagic solitary (e.g. Pope et al. 2010), the latitudinal temperature gradients of the Atlantic Ocean were not as strong as today, and the waters were warmer (Zachos et al. 2001; Bellwood \& Wainwright 2002; Bellwood et al. 2012), the fish could have inhabited the area during the Miocene.

\section{Acknowledgements}

Thanks to División Paleontología Vertebrados, Museo de La Plata, Universidad Nacional de La Plata, , CONICET, and Agencia Nacional de Promoción Científica y Tecnológica for supporting this research and science in general in Argentina. Partial funding was provided by the Agencia Nacional de Promoción Científica y Tecnológica [PICT 2015-0253 to SGC and PICT 2014-2357 to ALC]. Thanks to A. Elbakyan, A. Vaguelli (Center of Aquatic Sciences), D. Collautti, T. Maiztegui (ILPLA), H. López and D. Nadalin (MLP) who provided material for the comparative study and J. Casciotta (MLP) for their support. SGC thanks to L. L. Rasia (MLP) and J. Cuitiño (CENPAT) for constructive discussion on Miocene Atlantic 
marine trangressions in Argentina. We thank the reviewer J. C. Tyler for his detailed review of the manuscript and his kind words relative to our work; his suggestions and comments greatly improves the work presented. We thank to the editor, M. Laurin who handled the manuscript and make the review process goes smoothly. We deeply thank desk editor, A. Neveu for the proof improvements.

\section{REFERENCES}

ACeÑolaza F. G. 1976. — Consideraciones bioestratigráficas sobre el Terciario marino de Paraná y alrededores. Acta Geológica Lilloana 13: 91-107.

ACEÑOlaZA F. G. 2000. — La Formación Paraná (Mioceno medio): estratigrafía, distribución regional y unidades equivalentes, in AceNolazA F. G. \& Herbst R. (eds), El Neógeno de Argentina. Instituto Superior de Correlación Geológica, Serie de Correlación Geológica 14: 9-27.

Aceñolaza F. G. \& Aceñolaza G. 2000. - Trazas fósiles del Terciario marino de Entre Ríos (Formación Paraná, Mioceno medio), República Argentina. Boletín de la Academia Nacional de Ciencias 64: 209-233.

Aguilera O., Silva G. O. A., Lopes R. T., Machado A. S., Dos Santos T. M., Marques G., Bertucci T., Aguiar T., CarrilloBriceño J., Rodríguez F. \& Jaramillo C. 2017. - Neogene Proto-Caribbean porcupinefishes (Diodontidae). PLoS ONE 12: e0181670. https://doi.org/10.1371/journal.pone.0181670

ANDreuCCi R. D. \& BRITSKi H. A. 1982. - Structure and evolution of Tetraodontoid Teeth: An autoradiographic study (Pisces, Tetraodontiformes). Journal of Morphology 292: 283-292. https:// doi.org/10.1002/jmor.1051710304

ANTUNES M. T. 1978. - Faunes ichthyologiques du Néogène supérieur d'Angola, leur âge, remarques sur le Pliocène marin en Afrique Australe. Ciências da Terra 4: 59-90.

ANTUNES M. T., JONET S. \& NASCIMENTO A. 1981. — Vertébrés (crocodiliens, poissons) du Miocène marin d'Algarve occidentale. Ciências da Terra 6: 9-38.

Aramburu A. S. 1957. - Una nueva cita de Mola mola (Linné) para el Atlantico Sur (Pisces: Plectognathi). Notas del Museo de La Plata 19: 92-99.

ARCILA D. \& TYLER J. C. 2017. — Mass extinction in tetraodontiform fishes linked to the Paleocene-Eocene thermal maximum. Proceedings of the Royal Society B - Biological Sciences 284: 1-8. https://doi.org/10.1098/rspb.2017.1771

Arcila D., Pyron A., Tyler J. C., Ortí G. \& Betancur R. R. 2015. - An evaluation of fossil tip-dating versus node-age calibrations in tetraodontiform fishes (Teleostei: Percomorphaceae). Molecular Phylogenetics Evolution 82: 131-145. https://doi. org/10.1016/j.ympev.2014.10.011

Bannikov A. F., Tyler J. C., Arcila D. \& Carnevale G. 2017. A new family of gymnodont fish (Tetraodontiformes) from the earliest Eocene of the Peri-Tethys (Kabardino-Balkaria, northern Caucasus, Russia). Journal of Systematic Palaeontology 15: 129146. https://doi.org/10.1080/14772019.2016.1149115

Bellwood D. \& WAinwright P. C. 2002. - The history and biogeography of fishes on Coral reefs, in SALE P. (ed.), Coral Reef Fishes. Academic Press, Ontario, Canada: 5-32.

Bellwood D. R., Renema W. \& Rosen B. R. 2012. - Biodiversity hotspots, evolution and coral reef biogeography: a review, in Grower D. J., Johnson K., Richardson J., Rosen B., RÜBER L. \& WiLliams S. (eds), Biotic evolution and environmental change in Southeast Asia. Cambridge University Press, Cambridge: 216-245.

BerKovitz B. \& Shellis P. 2017. - The Teeth of Non-Mammalian Vertebrates. $1^{\text {st }}$ edition. Elsevier Academic Press, Amsterdam, $343 \mathrm{p}$.
Bertels A. 1970. - Sobre el "Piso Patagoniano" y la representación de la época del Oligoceno en Patagonia austral, República Argentina. Revista de la Asociación Geológica Argentina 25: 495-501.

Самасно H. 1967. - Las transgresiones del Cretácico Superior y del Terciario de la Argentina. Revista de la Asociación Geológica Argentina 12: 253-280.

Carnevale G. 2005. - Fossil fishes from the Serravallian (Middle Miocene) of Torricella Peligna, Italy. Palaeontographia Italica 91: 1-67.

Carnevale G. \& SAntini F. 2007. — Record of the slender mola, genus Ranzania (Teleostei, Tetraodontiformes), in the Miocene of the Chelif Basin, Algeria. Comptes Rendus Palevol 6: 321-326. https://doi.org/10.1016/j.crpv.2007.04.001

CiOnE A. L. 1988. - Los peces de las formaciones marinas del Cenozoico de Patagonia. PhD thesis, unpublished, Facultad de Ciencias Naturales y Museo, Universidad Nacional de La Plata, La Plata: 580.

Cione A. L. \& Azpelicueta M. M. 2002. - An Oplegnathid beak (Osteichthyes: Perciformes) from the Early Miocene of Patagonia. Extirpation of several vertebrates from the southern Atlantic Ocean. Geobios 35: 367-373. https://doi.org/10.1016/ S0016-6995(02)00032-3

Cione A. L., Azpelicueta M. M., Bond M., Carlini A. A., CasCiOTTA J. R., COZZuOl M. A., DE la Fuente M., Gasparini Z., Goin F. J., Noriega J., Scillato-Yané G. J., Soibelzon L., Tonni E. P., Verzi D. \& Vucetich M. G. 2000. - Miocene vertebrates from Entre Ríos Province, eastern Argentina, in Aceñolaza F. G. \& HerbSt R. (eds), El Neógeno de Argentina. Instituto Superior de Correlación Geológica, Serie de Correlación Geológica 14: 191-237.

Cione A. L., Cozzuol M., Dozo M. T. \& Acosta Hospitaleche C. 2011. - Marine vertebrate assemblages in the southwest Atlantic during the Miocene. Biological Journal of the Linnean Society 103: 423-440. https://doi.org/10.1111/j.1095-8312.2011.01685.x

Cione A. L., Cabrera D. A., Azpelicueta M. M., Casciotta J. R. \& BARLA M. J. 2013. — Peces del Mioceno marino y continental en Entre Ríos, oriente central de Argentina, in BRANDONI D. \& NoriegA J. I. (eds), El Neógeno de la Mesopotamia argentina. Asociación Paleontológica Argentina, Publicación Especial, Ciudad autónoma de Buenos Aires, 14: 71-83.

Close A. R., Johanson Z., Tyler J. C., Harrington R. C. \& Friedman M. 2016. - Mosaicism in a new Eocene pufferfish highlights rapid morphological innovation near the origin of crown tetraodontiforms. Palaeontology 59: 499-514. https://doi. org/10.1111/pala.12245

Cuitiño J. L., DOZO M. T., DEl Río C., BuONo M. R., PAlazzesi L., Fuentes S. \& SCASSO R. 2017. — Miocene Marine Transgressions: Paleoenvironments and Paleobiodiversity, in BOUZA P. \& Bilmes A. (eds), Late Cenozoic of Peninsula Valdés, Pantagonia, Argentina. An interdisciplinary approach. Springer: 47-84. https:// doi.org/10.1007/978-3-319-48508-9

DEL Río C. J. 1991. — Revisión sistemática de los bivalvos de la Formación Paraná (Provincia de Entre Ríos, Mioceno medio) de la Argentina. Academia Nacional de Ciencias Exactas, Físicas y Naturales 7: 11-93.

DEL Río C. J. 2000. - Malacofauna de las Formaciones Paraná y Puerto Madryn (Mioceno marino, Argentina): su origen, composición y significado bioestratigráfico, in ACEÑOLAZA F. G. \& HERBST R. (eds), El Neógeno de Argentina. Instituto Superior de Correlación Geológica, Serie Correlación Geológica 14: 77-101.

del Río C., Martínez S., Mcarthur C., Thirlwall M. \& PÉREZ L. M. 2018. - Dating late Miocene marine incursions across Argentina and Uruguay with Sr-isotope stratigraphy. Journal of South American Earth Sciences 85: 312-324. https:// doi.org/10.1016/j.jsames.2018.05.016

Di Giácomo E. E., Elías I., Alegre B., Gostonyi A. E. \& Perier M. R. 2015. - Peces marinos patagónicos, in ZaIXSO H. E. \& BORASO R. (eds), La zona costera patagónica Argentina, vol. III. Pesca y Conservación, Instituto de desarrollo costero, Edupa, Comodoro Rivadavia: 3-55. 
Dornburg A., Townsend J. P., Friedman M. \& Near T. J. 2014. - Phylogenetic informativeness reconciles ray-finned fish molecular divergence times. BMC Ecology and Evolution 14: 169. https://doi.org/10.1186/s12862-014-0169-0

Fraser G. J., Britz R., Hall A., Johanson Z. \& Smith M. M. 2012. - Replacing the first-generation dentition in pufferfish with a unique beak. Pnas 109: 8179-8184. https://doi.org/10.1073/ pnas. 1119635109

FrENGUELLI G. 1920. - Contribución al conocimiento de la geología de Entre Ríos. Boletin de la Academia Nacional de Ciencias de Córdoba 24: 55-256.

Gallo V., de Carvalho M. S. S. \& Souto A. A. 2009. - A possible occurrence of Diodontidae (Teleostei, Tetraodontiformes) in the Upper Cretaceous of the Paraiba Basin, northeastern Brazil. Cretaceous Research 30: 599-604. https://doi.org/10.1016/j. cretres.2008.12.001

Hernández R. M., Jordan T. E., Dalenz Farjat A., EchaVarría L., Idleman B. D. \& Reynolds J. H. 2005. - Age, distribution, tectonics, and eustatic controls of the Paranense and Caribbean marine transgressions in southern Bolivia and Argentina. Journal of South American Earth Sciences 19: 495-512. https://doi.org/10.1016/j.jsames.2005.06.007

HUYSSEUNE A. \& SIRE J.-Y. 1992. - Bone and cartilage re-sorption in relation to tooth development in the anterior part of the mandible in cichlid fish: a Ligth a TEM study. The Anatomical Record 234: 1-14. https://doi.org/10.1002/ar.1092340102

JohANSON Z. \& SMITH M. M. 2005. - Origin and evolution of gnathostome dentitions: a question of teeth and pharyngeal denticles in placoderms. Biological Reviews 80: 1-43. https://doi. org/10.1017/S1464793104006682

KemP A. 1997. - Four Species of Metaceratodus (Osteichthyes: Dipnoi, Family Ceratodontidae) from Australian Mesozoic and Cenozoic Deposits. Journal of Vertebrate Paleontology 17: 26-33. https://doi.org/10.1080/02724634.1997.10010949

KRIWET J. 2005. - A comprehensive study of the skull and dentition of pycnodont fishes. Zitteliana An International Journal of Palaeontology and Geobiology Series A/Reihe A Mitteilungen der Bayerischen Staatssammlung für Paläntologie und Geologie 45: $135-188$.

Moya-Smith M. \& Campbell K. S. W. 1987. - Comparative morphology, histology, and growth of the dental plates of the Devonian dipnoan Chirodipterus. Philosophical Transactions of the Royal Society B 317: 329-363. https://doi.org/10.1098/ rstb.1987.0066

Muizon B. C. D. E. \& Devries T. J. 1985. - Geology and paleontology of late Cenozoic marine deposits in the Sacaco area (Peru). Geologische Rundschau 74: 547-563. https://doi. org/10.1007/BF01821211

NARDO G. 1840. - Considerazioni sulla famiglia dei pesci Mola, e sui caratteri che li distinguono. Annali delle Scienze del Regno Lombardo-Veneto, Padova 10: 105-112.

Palazzesi L., Barreda V. D. \& Scasso R. A. 2006. - Early Miocene spore and pollen record of the Gaiman Formation (Northeastern Patagonia, Argentina): correlations and paleoenvironmental implications. $4^{\text {th }}$ Latin American Congress on Sedimentology and $11^{\text {th }}$ Argentinean Meeting of Sedimentology, Bariloche 2006: 161.

PARRAs A. \& CUITIÑO J. I. 2021. — Revised chrono and lithostratigraphy for the Oligocene-Miocene Patagoniense marine deposits in Patagonia: Implications for stratigraphic cycles, paleogeography, and major drivers. Journal of South American Earth Sciences 110: 103327. https://doi.org/10.1016/j.jsames.2021.103327

Parras A., Dix G. R. \& GRIFFIN M. 2012. - Sr-isotope chronostratigraphy of Paleogene/Neogene marine deposits: Austral Basin, southern Patagonia (Argentina). Journal of South American Earth Sciences 37: 122-135.

PéreZ L. M. 2013. - Nuevo aporte al conocimiento de la edad de la Formación Paraná, Mioceno de la Provincia de Entre Ríos, Argentina, in Brandoni, D. \& Noriega, J. I. (eds), El Neógeno de la Mesopotamia argentina. Asociación Paleontológica Argentina, vol. 14. Publicación Especial, Ciudad autónoma de Buenos Aires: $56-70$.

Pérez L. M., Griffin M. \& MAnCeñido M. 2013. — Los macroinvertebrados de la Formación Paraná: Historia y diversidad de la fauna bentónica del Mioceno marino de Entre Ríos, Argentina, in Brandoni D. \& Noriega J. I. (eds), El Neógeno de la Mesopotamia Argentina. Asociación Paleontológica Argentina, Ciudad autónoma de Buenos Aires: 56-70.

Pope E., Hays G. C., Thys T. M., Doyle T. K., Sims,D. W., Queiroz N., Hobson V. J., Kubicek L. \& Houghton J. D. R. 2010. - The biology and ecology of the ocean sunfish Mola mola: a review of current knowledge and future research perspectives. Reviews in Fish Biology and Fisheries 20: 471-487. https://doi. org/10.1007/s11160-009-9155-9

PoyATO-Ariza F. J. 2005. - Pycnodont fishes: morphologic variation, ecomorphologic plasticity, and a new interpretation of their evolutionary history. Bulletin of the Kitakyushu Museum of Natural History and Human History Series A Natural History, Series A: 169-184. https://www.jstage.jst.go.jp/article/ $\mathrm{kmnh} / 3 / 0 / 3 \_169 /$ pdf

RANZANI C. 1839. - Dispositio familiae Molarum in genera et in species. Novi Commentarii Academiae Scientiarum Instituti Bononiensis 3: 63-82, Pl. 6 + foldout table. https://doi.org/10.5962/ bhl.title.61542

Ryan W. B. F., Carbotte S. M., Coplan J. O., O'hara S., MelKONIAN A., ARKo R., Weissel R. A., Ferrini V., GoOdWILlie A., Nitsche F., BonCZKOwsKi J. \& ZeMSKY R. 2009. — Global Multi-Resolution Topography synthesis. Geochemistry, Geophysics, Geosystems 10: Q03014. https://doi.org/10.1029/2008GC002332.

SANTINI F. \& TYLER J. C. 2003. - A phylogeny of the families of fossil and extant tetraodontiform fishes (Acanthomorpha, Tetraodontiformes), Upper Cretaceous to Recent. Zoological Journal of the Linnean Society 139: 565-617. https://doi. org/10.1111/j.1096-3642.2003.00088.x

SCASSO R. A. \& CASTRO L. N. 1999. - Cenozoic phosphatic deposits in North Patagonia, Argentina: Phosphogenesis, sequence-stratigraphy and paleoceanography. Journal of South American Earth Sciences 12: 471-487. https://doi.org/10.1016/S0895-9811(99)00035-8

Sire J.-Y., Davit-Beal T., Delgado S., Van Der Heyden C. \& HUYSSEUNE A. 2002. - First-generation teeth in nonmammalian lineages: Evidence for a conserved ancestral character? Microscopy Research \& Technique 59: 408-434. https://doi.org/10.1002/ jemt. 10220

SMITH M. M. 1988. - The dentition of Palaeozoic lungfishes: a consideration of the significance of teeth, denticles and tooth plates for dipnoan phylogeny. Mémoires du Muséum national d'Histoire naturelle de Paris C 53: 177-193.

Smith K. A., Hammond M., Close P. G. 2010. - Aggregation and stranding of elongate sunfish (Ranzania laevis) (Pisces: Molidae) (Pennant, 1776) on the southern coas of Western Australia. Jour nal of the Royal Society of Western Australia 93: 181-188. https:// www.biodiversitylibrary.org/page/58034694

TraPani J. 2001. - Position of Developing Replacement Teeth in Teleosts. Copeia 2001: 35-51. https://doi.org/dgsv9d

TYLER J. C. 1980. - Osteology, phylogeny, and higher classification of the fishes of the Order Plectognathi (Tetraodontiformes). National Oceanic and Atmospheric Administration, Seattle: 422. https:// doi.org/10.5962/bhl.title.63022

Tyler J. C. \& BannikOv A. F. 1992. - New genus of primitive ocean sunfish with separate premaxillae from the Eocene of Southwest Russia (Molidae, Tetraodontiformes). Copeia 4: 10141023. https://doi.org/10.2307/1446631

Tyler J. C. \& Santini F. 2002. - Review and reconstructions of the tetraodontiform fishes from the Eocene of Monte Bolca, Italy, with comments on related Tertiary taxa. Studi e Ricerche sui Giacimenti Terziari di Bolca, Museo Civico di Storia Naturale di Verona 9: 47-119. 
TYLER J. C. \& SORBINI L. 1996. — New superfamily and three new families of Tetraodontiform fishes from the Upper Cretaceous: The earliest and most morphologically primitive Plectognaths. Smithsonian Contributions to Paleobiology 82: 1-59. https://doi. org/10.5479/si.00810266.82.1

UYENO T. \& SAKAMOTO K. 1994. — Ranzania ogaii, a New Miocene Slender Mola from Saitama, Japan (Pisces: Tetraodontiformes). Bulletin of the National Science Museum 20: 109-117.

Vélez-Juarbe J., Noriega J. \& Ferrero B. 2012. — Fossil Dugongidae (Mammalia, Sirenian) from the Parana Formation (Late Miocene) of Entre Rios Province, Argentina. Ameghiniana 49: 585-593. https://doi.org/10.5710/AMGH.27.6.2012.568

WeEMS R. E. 1985. - Miocene and Pliocene Molidae (Ranzania, Mola) from Maryland, Virginia, and North Carolina (Pisces: Tetraodontiformes). Proceedings of the Biological Society of Washington 98: 422-438. https://www.biodiversitylibrary.org/page/34648701
WoOdward A. S. 1901. - Catalogue of the fossil fishes in the British Museum (Natural History) Volume IV: Actinipterygian teleostomi of the suborders Isospondyli (in part), Ostariophysi, Apodes, Percesoces, Hemibranchii, Acanthopterygii, and Anacnthini. Longman \& Co. and the British Museum (Natural History), London: 636 p., 19 pls.

Wu F., Chang M., Sun Y. \& Xu G. 2013. - A new saurichthyiform (Actinopterygii) with a crushing feeding mechanism from the Middle Triassic of Guizhou (China). PLoS ONE 8: e81010. https://doi.org/10.1371/journal.pone.0081010

ZABERT L. L. 1978. - Micropaleontología de la Formación Paraná (Mioceno superior) en el subsuelo de la provincia de SantaFé, República Argentina. Facena 2: 101-165.

Zachos J. C., Pagani M., Sloan L., Thomas E. \& Billups K. 2001. - Trends, rhythms, and aberrations in global climate 65 Ma to present. Science 292: 686-693. https://doi.org/10.1126/ science. 1059412 